\title{
Making and Breaking the Working Class: Worker Recruitment in the National Textile Industry in Interwar Egypt*
}

\author{
H A N A N H A M A D \\ Department of History, Texas Christian University, Fort Worth
}

Email: h.hammad@tcu.edu

SUMMARY: This article examines how worker mediation to secure jobs for relatives and co-villagers in the nationalist textile industry influenced working-class formation in interwar Egypt. Mediation was conducted out of a sense of communal commitment or for commission, or indeed both. The fact that rank-and-file workers were able to intervene in the recruitment process reveals that workers were successfully able to manoeuvre in such a way as to balance their unjust work relations with the huge mill and to manipulate its system. On the other hand, this method of recruitment became a source of violence among workers when they fought one another, sometimes fatally, whenever one side failed to respect the terms of the financial arrangements agreed. In most cases it strengthened the communal solidarity based on kinship and geographical origin. In both cementing and distracting from working-class solidarity, worker interference in the recruitment processes was part of the developing sense of social transformation and bonding among a distinctive and connected professional community that hoarded its own bargaining power.

This article examines the process of worker recruitment for the modern national textile industry in interwar Egypt. Under the banner of nationalism and opposition to British occupation and foreign economic domination, Bank Misr established the largest Egyptian-owned textile factories in several locations during the interwar period. Bank Misr itself was established in I920 to finance Egyptian-owned, large-scale industrial enterprises under the slogan, "An Egyptian bank for Egyptians only". Thousands of male and female agricultural labourers and landless and near landless peasants of all

\footnotetext{
* I am indebted to the editors of this volume, especially Aditya Sarkar, for their useful comments on previous drafts of this article.

I. For a meticulous history of Bank Misr and its pioneering "national-capitalist" role, see Eric Davis, Challenging Colonialism: Bank Misr and Egyptian Industrialization, I920-I94I (Princeton, NJ, 1983).
} 
ages were brought from their villages to work in those factories, thus becoming industrial labourers and urban dwellers.

The rapid and impressive expansion of Bank Misr's companies was not associated with any systematic recruitment or training of workers. Workers themselves intervened in the apparently chaotic process of labour recruitment, securing jobs for their relatives and co-villagers. Sometimes this mediation was conducted out of communal commitment, and frequently the new workers were committed to pay a commission or a percentage of their salaries to the older colleague who had helped them get the job. This practice had long-term ramifications. On the one hand, the fact that rank-and-file workers were able to intervene in the recruitment process reveals that workers were successfully able to manoeuvre to balance their unjust work relations in huge factories and to manipulate its system. On the other hand, this method of recruitment became a source of antagonism and violence among workers. Workers fought one another, sometimes with fatal consequences, whenever one side failed to respect the terms of the financial arrangements agreed. In most cases it strengthened the communal solidarity among workers based on kinship and geographical origin. Spontaneously, workers were divided into fighting and competing groups, while their communal bonding facilitated their adaptation to industrial work and to coping with the urban setting.

Through the historical experience of the Misr Company of Spinning and Weaving in al-Mahalla al-Kubra (MCSW), I trace this recruitment process of rank-and-file workers and its consequences for both workers' interrelations and relations with the company. Contesting the ideas that employers had absolute power in choosing labourers in the abundant labour market, and that vehement, loud labour activism was the only efficient method for labour empowerment, the experience of the MCSW sheds light on the agency of seemingly powerless workers and their strategies for negotiating power within the gigantic company and nationalist, capitalist system. ${ }^{2}$ It also juxtaposes nationalist discourses on progress and modernization as embodied in the company with the opposing reality of the company's random and chaotic work practices. I argue that the modern, industrial disciplinary process of recruiting and training labourers in nationalist, capitalist factories were the site where both economic functioning and cultures interacted to shape the formation of an industrial working class and the development of its consciousness. Worker interference in the recruitment processes was itself part of the developing sense of social transformation and bonding as a

2. For a comprehensive treatment of the gap between discourse and practices of nationalist capitalism in interwar Egypt, see Robert Vitalis, When Capitalists Collide: Business Conflict and the End of Empire in Egypt (Berkeley, CA, 1995). 
distinctive and connected community that hoarded its own bargaining and negotiating power.

Ever since E.P. Thompson's seminal work, The Making of the English Working Class, scholars on working-class formation have been divided over the position of pre-capitalist ties and cultures in the development of working-class consciousness. Scholars acknowledge capitalists' utilization of racial and ethnic divisions among workers to distract them from workingclass solidarity. ${ }^{3}$ In many cases, however, shared ethnicity between workers and capitalists did not halt the development of working-class solidarity among workers who led labour protests against entrepreneurs of the same ethnic group. ${ }^{4}$ Yet, the issue of communal bonding throughout the processes of working-class formation is still problematic in the historiography.

Chakrabarty and others launched a sweeping critique of the Marxist analysis of labour history in Asia and Africa. ${ }^{5}$ Noting that, in particular circumstances, the most feudal system of authority can survive at the heart of the most modern of factories, they criticized the Marxist approach to working-class consciousness as one that undermined and even misunderstood culture, and criticized its assumption that working classes everywhere follow the European script for working-class formation. ${ }^{6}$ The historiography of the Middle Eastern working classes has been limited to the political activism and labour movements of factory workers and alienated social culture and its crucial rule in working-class formation. ${ }^{7}$ How "primordial" ties facilitated workers' adaptation to urban life while simultaneously promoting sectarianism has been treated as a dramatically exceptional case in Lebanon's torn society. ${ }^{8}$

In the case of Egypt, which this article focuses on, the available scholarship has treated the Egyptian working class as a Cairo-based phenomenon, with some attention given to Alexandria, Egypt's second-largest metropolis. ${ }^{9}$

3. Lex Heerma van Voss and Marcel van der Linden, Class and Other Identities: Gender, Religion and Ethnicity in the Writing of European Labour History (New York [etc.], 2002). 4. See, for example, Daniel Hiebert, "Jewish Immigrants and the Garment Industry of Toronto, I90I-I93 I: A Study of Ethnic and Class Relations", Annals of the Association of American Geographers, 83 (1993), pp. 243-271.

5. Dipesh Chakrabarty, Rethinking Working-Class History: Bengal, I890-1940, 2nd edn (Princeton, NJ, 2000), and Peter C.W. Gutkind (ed.), Third World Workers: Comparative International Labour Studies (Leiden, 1988).

6. Chakrabarty, Rethinking Working-Class History, p. xi.

7. For a good critique of the limitation of the Middle East working-class historiography, see Sherry Vatter, "Militant Journeymen in Nineteenth-Century Damascus: Implications for the Middle Eastern Labour History Agenda", and Assef Bayat, "Historiography, Class, and Iranian Workers"; both in Zachary Lockman (ed.), Workers and Working Classes in the Middle East (Albany, NY, 1994), pp. I-20 and 165-2 10 respectively.

8. Samir Khalaf, Lebanon's Predicament (New York, 1987).

9. Examples of this historiography include Joel Beinin and Zachary Lockman, Workers on the Nile: Nationalism, Communism, Islam, and the Egyptian Working Class, I882-1954 (Princeton, 
The workers' journey from recruitment to transformation into industrial labourers has been overlooked, together with their daily lives and routines inside and outside workplaces and trade unions, their interaction with other social groups, and the question of whether or not their experiences were distinct from the rest of the urban population. ${ }^{\circ}{ }^{\circ}$ In the existing literature, the peasant origin of most Egyptian industrial workers is neither denied nor well examined. Rather, it is merely cited as a source of limitation for the labour movement, and workers hailing from rural traditions are usually categorized

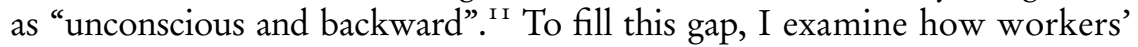
social origins, informal labour mediation strategies, and communal networks impacted their transformation into labourers within a new urban, industrial milieu, and shaped their working-class formation and identity.

\section{RECRUITMENT FOR NATIONAL SUCCESS}

From the eighteenth century onward, the town of al-Mahalla al-Kubra, in the middle of the Nile Delta, emerged as an important textile industry centre in Egypt and the Ottoman Empire. In 1927 the Egyptian nationalist economist and founder of Bank Misr, Tal'at Harb, chose the town as the site for the MCSW. This was the first large, Egyptian-owned textile factory in Egypt, and it remains one of the biggest today. The MCSW also became Bank Misr's flagship company and most successful enterprise, employing the largest number of industrial workers in the country. By the end of 1930, the factory's products had successfully gone to market, which encouraged the owner of Bank Misr to expand it continually. The workforce rapidly increased from approximately 2,000 workers in 1930 to I0,000 in 1938 , and then to 27,000 in 1945 . Such rapid expansion helped construct the company within Egyptian nationalist discourse as an emblem of national success and progress in the face of foreign political and economic domination. Throughout the I930s and I940s, commercial advertisements frequently appeared in Cairo's press, promoting and exalting the MCSW as a national icon by stating, for example, "Every dress you wear that is made in the Misr Company is a banner of our

\footnotetext{
NJ, 1988), and Ellis Goldberg, Tinker, Tailor, and Textile Worker: Class and Politics in Egypt, 1930-1952 (Berkeley, CA, I986). The notable exception in terms of greater consideration being given to working conditions in al-Mahalla, rather than to the labour movement there, is Joel Beinin's chapter "Fikri al-Khuli's journey to al-Mahalla al-Kubra", in idem, Workers and Peasants in the Modern Middle East (Cambridge, 200I), pp. 99-1 I 3.

I0. Samer Said Shehata, Shop Floor Culture and Politics in Egypt (Albany, NY, 2009), is a notable exception in terms of how it broadens the discussion on working-class formation to include social networking and social dynamics on the shopfloor.

II. See Taha Sa'd 'Uthman, Mudhakkarat wa-watha'iq min tarikh 'ummal Misr: Kifah 'ummal al-nasij 1938-1947 [Memoirs and Documents from the History of Egypt's Workers: The Struggle of Textile Workers, 1938-1947], 2 vols (Cairo, I982-1983).
} 
national freedom". However, that rapid and impressive expansion was not associated with any systematic recruitment or training of workers.

At its beginning, the company sent dozens of technical school graduates to Europe for training to prepare them to train others upon their return to Egypt. It also depended on experienced handloom weavers among the local population of al-Mahalla to train unskilled workers with no previous experience of industrial practices. The local townspeople's expertise in handloom weaving was one obvious reason why Bank Misr chose al-Mahalla for its flagship textile company. In his 1924 inauguration speech for the Bank Misr branch in al-Mahalla, Tal'at Harb expressed great admiration for the people of al-Mahalla and their commitment to education and industry, particularly the textile industry. He pointed out that 57 per cent of al-Mahalla's population worked in industry (and almost one-third of the population worked in the textile industry), while only 26 per cent worked in agriculture and 17 per cent in commerce, which he considered the ideal balance in terms of economic activity. ${ }^{\mathrm{I}}$ The theory was that the textile industry had become so much a part of the culture of the town that its children were effortlessly predisposed to acquire its skills and traditions, and that consequently the shift from handloom to mechanical weaving should not be difficult. ${ }^{13}$

The prospect of working at the MCSW was not initially attractive to the townsmen due to its poor wages and night shifts. Handloom weavers who joined the company and contributed to the training of its pioneer workforce quit shortly after realizing that their company wages were less than they had earned in the handloom workshops. The MCSW sent low-ranking, whitecollar workers from Bank Misr to rural villages to recruit workers from among the peasantry. Despite their lack of industrial skills, workers from rural areas were seen as an asset because they were believed to possess a simple, obedient character, making them more inclined to submit to rigid discipline. ${ }^{\mathrm{I}}$ The white-collar workers dispatched to recruit peasants were afandiyya, the modern, educated middle class of Egypt. They used a strong nationalist discourse and lured peasants with promises of a comfortable urban life with guaranteed living accommodation.

A recruitment visit by an afandi to a village typically began with a meeting with the head of the village ("umda), whose cooperation was the

I2. Tal'at Harb, Majmu'at Khutab Muhammad Tal'at Harb [A Collection of Tal'at Harb's Public Speeches] (Cairo, I927), p. IоI.

I3. Nawal Isma'il, "Madinat al-Mahalla al-Kubra: Dirasa fi jughrafiyyat al-'umran" [The City of al-Mahalla al-Kubra: A Study in Urban Geography] (M.A. thesis, 'Ain Shams University, Cairo, 1965), pp. I8-19.

14. Frederick Harbison and Ibrahim Abdelkader Ibrahim, Human Resources for Egyptian Enterprise (New York, 1958), p. 69. 
key to the success of the recruitment mission. He also met local school teachers, bureaucrats, and students - with whom he shared the title of afandi and the nationalist drive and championing of Bank Misr and its industrial enterprises. Although Bank Misr was ostensibly founded to help Egyptian landowners diversify their investments and was technically under their control, it was primarily embraced by the rising, educated middle class, the afandis. In keeping with the traditional method for publicizing news and information among illiterate villagers, public cryers roamed the villages to urge men and women, children and adults, to gather in the courtyard (dawwar) of the 'umda. There, the afandi recruiter spoke to the rural poor about abundant job opportunities in Bank Misr's big new textile factory in al-Mahalla al-Kubra.

In their discourses, afandiyya mixed their recruitment agenda with their nationalist mission, in which the ultimate goal was to attract rural peasants into urban, industrial work and immerse them in nationalist ideology. Afandiyya preached how great it was to have an Egyptian-owned factory buy the Egyptian cotton that Egyptians cultivated to make clothes that Egyptians could wear. Thus, "everything would be from Egypt for Egyptians", rather than having the British buy Egyptian cotton only to resell British-manufactured clothes to Egyptians. Such nationalist discourse was not only disseminated among peasants by employers of Bank Misr but also by the 'umadas (village mayors), political activists, and local afandis residing in villages, such as professionals, techno-bureaucrats, school teachers, and high school and college students. For example, leftist labour activist Muhammad Shata, who joined the MCSW in the early I930s as a twelve-year-old boy, learned about the factory in al-Mahalla from his elementary school teacher. ${ }^{\text {Is }}$ In his Arabic composition lessons, the teacher gave lectures about Bank Misr, its textile factory in al-Mahalla, and the bank founder and nationalist economist Tal'at Harb. Even in villages where afandiyya recruiters did not visit, others urged those who wished to earn a living to join the al-Mahalla factory.

Landless peasants may have needed to be informed about job opportunities in al-Mahalla, but it is doubtful whether the massive numbers that joined the MCSW did so in direct response to the recruiters' nationalist discourse. Owing to the increasing concentration of land ownership, more peasants became landless agricultural labourers, or struggled to secure small landholdings through seasonal agricultural labour. Working at the MCSW thus seemed an attractive solution to their unemployment problem. The recruiting afandiyya and village cryers promised that peasant children would learn a good profession (san'ab) by becoming 
industrial workers in al-Mahalla, and that good wages would be paid to anyone who completed the training. The 'umadas endorsed these promises as well as announcements publicizing the time and place from which the afandiyya would transport those who wanted to work in the factory. ${ }^{16}$ Stories about children going to work in al-Mahalla and then returning to their home villages a few months later wearing new clothes also persuaded the rural poor to believe the rhetoric about better urban living standards, higher wages, and better work conditions in the factories. Moreover, the prospect of working at the factory meant permanent work and rescue from the elements instead of seasonal, agricultural labour in outdoor fields. ${ }^{17}$

The sight of big trucks arriving to pick up those willing to leave their homes to join the factory in al-Mahalla was already very familiar in these villages. It was almost identical to the sight of trucks picking up and transporting landless village peasants to work in distant fields. Land ownership became increasingly concentrated in the late nineteenth century, particularly after the onset of British occupation in $\mathrm{I} 88 \mathrm{I}$, and labour contractors seasonally shipped male and female labourers from villages with large numbers of landless peasants to work on large farms or construction sites hundreds of miles away. ${ }^{18}$ These seasonal workers were known in their home villages as tarabila (roaming workers), whereas people in their host villages sometimes derogatorily called them gharraba (aliens). During these seasonal trips for work, men, women, and children worked long hours under the harsh sun in the summer and in the cold in the winter. They slept in hasty, makeshift shelters made of thin burlap and rags. Given this history, it is unsurprising that the Maballawiyya (townspeople of al-Mahalla) likewise referred to the new influx of poor villagers arriving to work at the factory as gharraba and shirkawiyya (people of the company).

The profession of labour contracting was understood to be restricted to men. However, the archival records on which this study relies reveal that there were also female labour contractors and subcontractors in areas surrounding al-Mahalla al-Kubra. Those female contractors performed the same tasks of recruiting village labourers for agriculture and construction

16. Fikri Al-Khuli, al-Ribla [Journey], 3 vols (Cairo, I987-I99i), I, p. I7.

17. Al-Sa'id, Arshif al-Yasar, p. 288.

I8. For the history of agricultural workers, Tarabila, see Sawsan el-Messiri, "Tarahil Labourers in Egypt”, in Alan Richards and Philip L. Martin (eds), Migration, Mechanization, and Agricultural Labor Markets in Egypt (Cairo, 1983). See also Fatimah 'Alam al-Din Abd al-Wahid, Tarikh al-'Ummal al-zira'iyyin fi Misr, 19I4-1952 [History of Agricultural Labourers in Egypt, I9I4-1952] (Cairo, I977), and 'Atiyyah al-Sayrafi, 'Ummal al-tarabil (Cairo, 1975). In his social-realist novel, al-Haram [Sin] the Egyptian author Yusuf Idris deals exclusively with the moral and material dilemma of a female Tarabila worker; Yusuf Idris, al-Haram (Cairo, 1965). 
sites, and riding trains and pick-up trucks to escort them to other villages and towns. Among these women was 'Aziza Hassan al-Tiryaqi, who agreed to recruit labourers for the 1937 cotton season and share the profit with a male labour contractor, al-Birins Mirsal al-Sudani. When al-Birins failed to comply with their agreement, paying her only EGP I.4 instead of the agreed EGP 3 (half the profit), she sued him and won her case. ${ }^{19}$ Another female labour contractor was Fatima Ali al-Dali, who recruited workers to harvest cotton in the 1945 season in the nearby village of al-Mu'tamadiyya. She had to accompany male and female labourers to their work sites and wait with them until the end of the workday. She ran the risk of having some of her recruited labourers rejected by farm managers due to poor health or bad reputation. She was also robbed by some of the workers she recruited. ${ }^{20}$

With the integration of Egypt into the global market as a cotton exporter in the late nineteenth century, labour contractors also shipped the rural poor to work in cotton gins. The work was seasonal, and many of the labourers were women and children. The Deputy Director of the International Labour Organization, Harold Butler, noted in his 1932 report that women and children worked in cotton gins in deplorable conditions, and workers of all kinds were not only poorly paid but often cheated out of their meagre earnings by unscrupulous employers and labour contractors. ${ }^{2 \mathrm{I}}$

Formal labour contractors were absent in the transportation of peasants seeking work at the MCSW in al-Mahalla. This, in itself, implied that the peasants recruited would receive the full share of their wages. However, the afandiyya's promise that the company would provide workers with accommodation proved false. What the MCSW actually provided at the beginning was permission for workers to sleep in the company's courtyards for a few weeks. ${ }^{22}$ The rapid increase in the workforce population and the company's incessant drive for expansion were used as excuses by the company for making workers arrange their own accommodation. Many workers slept inside bakeries, animal sheds, marketplaces, and alleys, and along railway lines and canal banks. ${ }^{23}$

After the company became highly publicized across Egypt as a major job provider, thousands of peasants travelled on their own from all over

19. Al-Mahalla Civic Court Records 1939, file 66 I 2, case 2503 , Archive of Dar al-Mahfuzat al'Umumiyah bil-Qal'ah.

20. Al-Mahalla Misdemeanour Court Records 1945 , file 7795, case 3389. Hereafter this source will be cited using the following format: "Misdemeanour 1945/7795/3389".

21. Harold Butler, Report on Labour Conditions in Egypt with Suggestions for Future Social Legislation (Cairo, 1932), p. I4.

22. See al-Khuli, al-Ribla, I, pp. 28-3i, and al-Sa'id, Arshif al-Yasar, p. 284.

23. Misdemeanour $1938 / 899$ and Misdemeanour $1936 / 6767 / 1762$. 
the country to al-Mahalla, hoping to be employed. The company's demand for labourers was relentless due to its rapid expansion and the high labour turnover rate. It was common for workers to quit and then return later to the company. ${ }^{24}$ The greatest rates of absenteeism occurred during workers' first week of employment, the most difficult period of adjustment for those who had never operated heavy, industrial machinery. Adjustment to factory routine, operational training, group work, and abusive foremen was difficult, and was aggravated by the lack of a worker-orientation programme. Many workers assumed factory employment did not require their presence every day. If they had families with small landholdings, or if their landlord offered temporary work during the planting or harvesting seasons, workers - particularly new recruits - might remain in their villages for a few days, thinking they could resume work at the factory when they had finished with their agricultural job.

As early as April I93I, just four months after the MCSW produced its first piece of cloth in December 1930, the administration started to complain about the extraordinary absence of workers "without an excuse, which forces the company to train others". ${ }^{25}$ Many workers joined the company with the intention of returning to their home villages once they had saved some cash. Many more quit when they discovered the promises of the afandiyya recruiters to be false. Bad working and living conditions spurred even more workers to quit. The problem was so acute that the company perpetually had to train more workers than it needed just to be ready to cover those who would drop out. In I94I the MCSW administration finally objected, stating that "large numbers of our trained workers leave our factory every day with one group following another". ${ }^{26}$ This time, the reason for the high turnover rate was clear, and the administration admitted that workers were "seeking higher wages". ${ }^{27}$ The high rate of worker absenteeism and resignations resulted in a tangible reduction in production in I943, when the company attributed the phenomenon to seasonal agricultural work and the attractive wages offered by other new, competing factories. ${ }^{28}$

That many workers would actually prefer agricultural work, known to be among the lowest-paid occupations, over factory work at the MCSW revealed the irony that wages for menial agricultural labour were still

24. MCSW, Sijil Tarikhi Sharikat Misr lil-Ghazl wal-Nasij [Historical Record of the Misr Company for Spinning]. It comprises unpublished undated documents.

25. Ibid.

26. Sharikat Misr lil-Ghazl wal-Nasij: al-Taqrir al-Sanawi li-Majlis Idaratiha al-Muqadam lilJam'iyya al-'Umumiyya lil-Musabimin [Misr Company of Spinning and Weaving: Annual Report of the Board submitted to the General Meeting of Shareholders] (Cairo, I94I).

27. Ibid.

28. MCSW, Sijil Tarikhi Sharikat Misr. 
higher than those that the company was prepared to pay. Yet another irony was that, while the company preferred workers of peasant origin due to their perceived submissiveness, many such workers considered factory work at the company merely a reserve occupation for when there was a shortage of agricultural work. There is no question that meagre pay and severe working conditions precluded worker loyalty to the company and commitment to industrial work. Returning to agricultural work whenever it was available was in effect a form of resistance against the company's injustices in the manner that James Scott describes as "everyday forms of resistance" among oppressed peasants, and that Asef Bayat calls "quiet encroachment of the ordinary" among the urban poor. ${ }^{29}$ Quitting work was one way of resisting the unjust work relationship with the MCSW, and it exposed the dire lack of a systematic company policy for recruiting and retaining workers.

\section{RECRUITING GOOD SUBJECTS}

MCSW job candidates regularly waited in the company yard, where a uniformed officer, typically a retired, high-ranking army official employed by the company to police its workforce, would randomly chose new workers. ${ }^{3 \circ}$ Candidates did not fill out forms or job applications. Rather, the officer would simply select from among the gathered candidates those whom he judged to be good subjects and determine, again using his own judgement, at which section they were qualified to work. Records show that young men between the ages of sixteen and twenty-five were usually chosen for the weaving section, and older men were directed to the yarn sections or to work as porters. Children were also often directed to work in the yarn and preparation sections.

Department heads reserved the right to judge the suitability of candidates before submitting them for medical examination and criminal background checks. The arbitrary, haphazard selection process was based on individual officers' experience and personal judgement in discerning who would be a docile worker. Candidates who showed any hint of alertness or aggressiveness were branded as potential troublemakers and

29. James C. Scott, Weapons of the Weak: Everyday Forms of Peasant Resistance (New Haven, CT, 1985), idem, "Everyday Forms of Peasant Resistance", Journal of Peasant Studies, I3:2 (1986), pp. 5-35, and Asef Bayat, Street Politics: Poor People's Movements in Iran (New York, 1997).

30. The recruiting scene given here is based on many court cases; Muhammad Yusuf al-Mudarrik, Hawla Mushkilat 'Ummal al-Maballa [On the Problem of Workers in al-Mahalla] (Cairo, 1947), and the memoirs and autobiographies of four pioneer workers. See Asma Halim, Kikayat ' $A b d u$ 'Abd al-Rabman [The Story of 'Abdu 'Abd al-Rahman] (Cairo, I977); 'Atiyyah al-Sayrafi, Sirat 'Amil Mushaghib [An Autobiography of a Trouble-Making Worker] (Cairo, 2007); al-Sa'id, Arshif al-Yasar; and al-Khuli, al-Ribla. 
bypassed. ${ }^{3 \mathrm{I}}$ From the early moments of recruitment, ghafar (guards) practised their disciplinary mission by using batons to line the job candidates forcibly into rows and keep them quiet until the officer had completed his selection. ${ }^{32}$ The primary mission of company guards and police was to control workers rather than guard the company's property. City policemen were always visible around the MCSW's property, and at the routes leading to its facilities, to control traffic and push people away from the company gates. Police forces were always willing to help control workers, and workers often complained of excessive and cruel police harassment. ${ }^{33}$

A few years after its establishment, increasing demand for factory work led the MCSW to develop a system to exclude candidates with criminal records, anyone who had previously joined the company and been fired or quit, and anyone with incurable health problems. This exclusion policy was applied with particular rigidity against job candidates with tuberculosis or poor vision. ${ }^{34}$ When a job candidate was selected by the officer at the company gates, a form was completed with his name and place of origin (balad), and the candidate's photograph attached. The completed form would be sent to the respective department manager to determine whether the nominated candidate was a good fit. The candidate would then undergo a medical examination to screen for diseases and to ensure that his or her sight was sufficient. A clerk would pore through company files to see whether the candidate had previously worked there and been fired or quit. Candidates with criminal records were screened out by a background check of government records, a procedure for which the candidate had to pay I 3 piastres.

If the candidate's record was clean, that person would finally be confirmed for a job at the factory and receive a worker ID card with name, photograph, and serial identification number. The demand for work was so high that the company at first had to conduct the selection session a few times a week, and then once a month. The hiring process forced candidates to cover the procedural costs of criminal background checks and photographs themselves. In 1947 the cost of such a file was 24 piastres, equivalent to nearly two weeks' wage for the average worker. ${ }^{35}$ The high costs served to deter workers from quitting the company after a few days, particularly

31. Harbison and Ibrahim, Human Resources for Egyptian Enterprise, p. 74.

32. For one of the many incidents in which ghafar injured candidates while forcing them to line up, see Misdemeanour 1942/6792/2649.

33. Misdemeanour 1945/7793/1865, and Misdemeanour 1938/6776/2177.

34. Sharikat Misr lil-Ghazl wa al-Nasij al-Mahalla al-Kubra, Taqrir 'ann al-a'mal al-tibiyya [Misr Company of Spinning and Weaving: A Report on Medical Activities] (Cairo, I95 I), p. 5 .

35. Al-Mudarrik, Hawla Mushkilat 'Ummal al-Mahalla, pp. I3-14. 
when they discovered that they had to pay the same costs each time they left and tried to rejoin the company.

Informal labour mediators emerged in this chaotic, multi-step hiring process to assist others in winning company jobs. A delicate balance between formality and informality was, arguably, negotiated daily through mediation. The formal regulation at the factory - the presence of police officials, medical inspection, and worker registration - provided opportunities for subversion and manipulation by workers and others, and thus established the possibility of informal mediation. In most cases mediators were company workers who had experience of the hiring system, enjoyed good connections with bosses, and had access to company labour files. They helped candidates skip the humiliation of having to endure the long hours of the selection process by the company gates, and they even helped candidates who did not pass the selection.

After quitting school and migrating to al-Mahalla to seek a company job, Muhammad Shata joined other job candidates by the company gates for several days, but the recruiting officer never selected him. Eventually, a factory worker offered to help him get a job in return for two weeks' wages. Shata's wages were I piastre a day for a 13 -hour shift. ${ }^{36}$ The clustering of "corrupt" or "informal" practices was a consequence of the nature of formal regulation at the factory and encouraged informal mediation. Mediators also helped those who failed to join the company owing to their having a criminal record or poor health. Workers, who were supposed to be powerless subjects, were thus able to manipulate the system and expose its limitations. The company's hiring process was so ineffective that many workers with criminal records and others with a history of quitting were able to sidestep the process to get hired. ${ }^{37}$

Among the many cases of individuals with criminal records joining the company, the case of al-Yamani Zahran al-Gallad provides insight into the extent to which mediators were able to subvert the system. Twenty-threeyear-old MCSW employee, al-Yamani, lived in the workers' slum of Muhammad 'Ali Street. ${ }^{38}$ On I4 August 1943, while strolling along Railway Station Street (the largest boulevard in the modern commercial centre of al-Mahalla), al-Yamani was spotted by 'Ali al-Dib, a policeman, who was familiar with his criminal record. The policeman was suspicious because al-Yamani was known for committing theft and violent crimes (I'tida' 'ala al-nafs wa al-amwal), so he took him to the police station to investigate how he made a living. Al-Yamani said he worked for the MCSW and showed his worker ID card. The ID card displayed his

36. Al-Sa'id, Arshif al-Yasar, pp. 282-288.

37. Tanta Criminal Court Record I943/7455/273 I, Archive of Dar al-Mahfuzat al-'Umumiyah bil-Qal'ah.

38. Ibid. 
photograph under the alias 'Abdulla Ibrahim al-Mansi, and al-Yamani confessed that he adopted that name because he had a criminal record that would have prevented him from getting the job. Company sources indicated he had been working under that alias since I 8 June I943. Clerks had followed the usual criminal record investigation procedure (fish wa tashbib), with the Department of Identification reporting that his record was clean. To show the level of the system's inefficiency, 'Abdulla Ibrahim al-Mansi turned out to be a real person living in the village of Shunu in the province of Kafr al-Shaykh.

Workers with criminal records who joined the company with help from mediators were discovered only when they were apprehended for unrelated incidents. Police discovered that the eighteen-year-old factory worker Hilmi Muhammad Khattab had a criminal record when he was arrested for pickpocketing Batta 'Abd al-Latif. ${ }^{39}$ Similarly, when thirty-six-year-old Hilmi Hamuda al-Zayyat was arrested in July 1938 for attempting to steal a piece of cloth from the MCSW, it was revealed that he had a criminal record, with four previous arrests, and was consequently given a harsh sentence of four months in jail with six months' probationary surveillance..$^{40}$ Al-Zayyat's colleague, twenty-eight-year-old Zakariya Ali al-Bilihi, was also caught hiding a piece of MCSW cloth under his clothes in late 1940, and al-Bilihi was discovered to have committed three crimes in the past. He was sentenced to four months in jail for a previous offence in August 1940. Police records had labelled him a suspected criminal (mashbub) earlier that year, but despite his extensive criminal record mediators enabled him to join the company and pass the background check. Al-Bilihi was also sentenced to six months in jail and given three months' probationary surveillance. ${ }^{4 \mathrm{I}}$

As a way of augmenting their income, some experienced workers took advantage of the hiring process by deliberately seeking random individuals searching for work and helping them secure jobs in return for one-off, fixed fees. They showed their company IDs to convince potential candidates of their ability to guide them through the hiring process. Ma'addawi Ibrahim Galalah charged Abd al-Qadir Ghazi Salamah iso piastres in exchange for a position as either a factory worker or guard after passing the medical examination. Upon being caught, Salamah was sentenced to four months in jail, with labour, and bail was set at EGP $5 .{ }^{42}$

39. Misdemeanour $1939 / 6779 / 47$.

40. Misdemeanour 1939/6779/138.

4I. Misdemeanour $1940 / 2007$. For more incidents involving workers with criminal records, see Misdemeanour 1945/7791/363 and 7791, and 1938/6775/100 and 775. See also Tanta Appeal Court Record 1948/7564/1365, from which it appears that Salih Mas'ud Khairallah, who was caught stealing a piece of cloth, had nine crimes on his record.

42. Misdemeanour $1935 / 6783 / 4613$. 
Some mediators specialized in helping job candidates who failed the medical examination; they navigated the internal networks and used bribery to help candidates pass. Others made a living from counterfeiting medical reports and ID cards. Mediators bribed officials in the Department of Health, for example, to pass unqualified candidates. In one particular case, a mediator convinced a candidate that he could get him the required medical report if he gave him EGP I.s to bribe the doctor; the mediator took the money and disappeared..$^{43}$ Administrators at the MCSW Labour Office eventually discovered that some candidates who had failed the medical examination were able to get jobs in the company without ID cards. After an investigation, thirteen-year-old Ibrahim Muhammad Zarra was caught with a fake ID card, complete with company seal. Zarra had migrated from his village of Shubra Babil to al-Mahalla hoping to join the company workforce. Though he had passed the preliminary selection process at the company gates, his application was rejected because he had failed the medical examination. Two of his colleagues, whose names were not revealed in the investigation, sold him the fake ID, which enabled him to join the company and get paid. ${ }^{44}$ The ID card displayed the fraudulent signatures of two high-ranking company administrators, which indicates the degree to which the mediators were familiar with the company administration and internal system.

Though the names of the mediators were not disclosed in the case of Zarra, cases such as his indicate that at least some of these mediators were mid-level, white-collar workers, and administrators at the company's Labour Office, with access to company records. The case of job candidate Girgis Salib presents yet another example. Salib gave his photo to 'Abd al-Hamid Ahmad Badr, a cook who acted as his mediator. ${ }^{45}$ Salib paid a fixed fee in return for a counterfeit company ID, complete with his photograph, company seal, and signature of the Labour Office head. Curiously, all the workers caught with fake ID cards were men, while no reports exist of female workers being caught for such fraud. Considering that there were about 2,000 women among the company's workforce of 20,000 people, it may be assumed that some female workers might have secured their factory positions through a similar mediation system but were simply never caught. The fact that no women were reported indicates that either none were caught, or that their cases were settled before reaching court. It is also reasonable to assume that female workers with fake company IDs were fewer in number, and female job candidates were more likely to look for other jobs in smaller textile factories or domestic labour if their applications were rejected. 
Mediators also helped workers sidestep the company's policy of not rehiring those who had quit or dropped out of work. The most common trick employed to do this was to change their names every time they needed to rejoin the company. The company's fingerprint system failed to catch them, unless they were arrested for some incident. ${ }^{46}$ Others were able to take advantage of the company's inefficient bookkeeping to add fake names to the payroll lists and claim wages for non-existent people. Company worker Rushdi As'ad Rufa'il was able to add twenty names to the payroll before being caught. With fake ID cards and seal stamps, he collected money for non-existent workers and for others who did exist but had never actually worked at the company. His fraud was very successful, and he embezzled 427 piastres between September 1935 and February 1936. He was caught only by chance when his landlord found his fake stamps and ID cards. ${ }^{47}$

Not all worker mediation was conducted in exchange for a commission or percentage of wages. Workers also mediated to secure company jobs for their relatives and co-villagers. In the early i940s, 'Atiyyah al-Sayrafi was forced to quit his studies at the Zaqaziq Islamic School owing to poverty and to search for work while still a child..$^{4}$ After failing to find a job in his hometown of Mit Ghamr, his mother planned to take him to al-Mahalla to secure a job at the MCSW. While she waited for the train at the Delta Railway Station in Zifta, along with workers from various provinces on their way to al-Mahalla, al-Sayrafi's mother asked how she could find a job in the factory for her son. The workers volunteered to take care of the boy through the early morning selection process and get him a job. She gave them 20 piastres to support her son until he got paid. The workers accommodated 'Atiyyah al-Sayrafi in their room in the workers' slum of Abu Gahsha, and at 7 am the following day they escorted him to the company gates, where he was selected for work in the spinning section. He went to the company's Labour Office to register his name and personal information so as to start work the following day. In his memoir published in 2007, 'Atiyyah al-Sayrafi, a veteran labour activist, reflected on the humiliation he felt during the initial selection process at the gates:

In an atmosphere of terror, about 300 new workers were driven by the factory guards to a big yard, which was [like] a bazaar for the sale of human workforce for MCSW. Workers who came to sell their labour were asked to sit down on the floor so that their [physical] features could be inspected, as if they were

46. Misdemeanour 1938/6775/100 and 775; Misdemeanour 1939/6779/47 and I38; Misdemeanour 1940/2007; Misdemeanour 1945/7791/363 and 7791.

47. Misdemeanour $1936 / 6766 / 852$.

48. Al-Sayrafi, 'Amil Mushaghib, pp. 68-70. 
slaves in a slavery market. In that dehumanizing exhibit, guards lashed obscene words to our faces although we were totally silent. ${ }^{49}$

In 1929, at the age of twenty, 'Abdu 'Abd al-Rahman earned a diploma from a vocational high school in the town of Damanhur. ${ }^{50} \mathrm{He}$ worked on his uncle's estate for three years before migrating to al-Mahalla, where he started working at the MCSW in 1932. The day he arrived, a porter at the railway station recommended that he go to a coffee shop located next to the company buildings, where he could find people who could secure a job for him. At the coffee shop, al-Rahman ran into an old schoolmate from Damanhur, Muhammad Fahmi. ${ }^{\text {sI }}$ Fahmi and his roommate, 'Ali Muhammad, took 'Abd al-Rahman's birth certificate and school diploma to the factory administration and secured a job for him immediately. On the following day, when he went with them to work, he discovered that both of them had arranged everything for him and exempted him from all the hassles of the screening process. He operated a loom for 7 piastres a day for a Io-hour shift. In the case of 'Abd al-Rahman, kinship, geographical origin, and collegial ties played a key role in his labour mediation.

Another example of how workers were able to negotiate the system to help each other gain jobs and promotion is that of pioneer worker, Fikri al-Khuli. In his three-volume memoir, al-Khuli gives a vibrant account of his experiences working at the MCSW, spanning the period of his early days at the age of eleven until he was fired and imprisoned in 1942 for participating in labour activism. ${ }^{52}$ Although al-Khuli's memoir contradicts the nationalist narrative, his depiction of working and living conditions in al-Mahalla is consistent with contemporary documents published by leftist activist Yusuf al-Mudarrik in 1947 as well as with the court records utilized for this study and the oral testimonies I collected in al-Mahalla. ${ }^{53}$

Fikri al-Khuli travelled as a child from his village of Kafr al-Hima to al-Mahalla searching for two friends who had gone to work at the factory. He met them at the factory gates at sunset as they arrived to start their night shift (between $8 \mathrm{pm}$ and $7 \mathrm{am}$ ), and walked with them as they went inside the factory. On the busy shopfloor, one of the bosses came and registered al-Khuli's name among the workers present and instructed him, and the other children, to pick up bobbins from the spinning machines. This was how he accidentally joined the MCSW, to become a child labourer in the factory's spinning section. ${ }^{54} \mathrm{~A}$ few weeks later, al-Khuli

49. Ibid., p. 69.

50. Halim, Kikayat 'Abdu 'Abd al-Rabman, p. 5.

5. Ibid., pp. 28-30.

52. Al-Khuli, al-Ribla.

53. On the position of al-Khuli's account in the nationalist narrative, see Beinin, Workers and Peasants in the Modern Middle East, pp. 99-1 I3.

54. Al-Khuli, al-Ribla, I, pp. 23-24. 
wandered into the weaving section out of curiosity. The weaving machines were smaller than the spinning machines, and the workers were a bit older. He asked the section boss to allow him to join that section. Initially, the boss refused because al-Khuli was too young and too short. After some begging, with al-Khuli claiming he was an orphan who needed a higher wage to support his mother, the boss relented and ordered one of the weavers to train him. Thus, al-Khuli became a weaver at the factory, and his daily wage increased from I piastre to 2.5 piastres. ${ }^{55}$

His room-mates and friends in the spinning section then asked him to help them join the weaving section since they had helped him join the company. The following day, he went with them to his section boss, asking for them to be hired as well. They pleaded that they were roommates from the same village and needed to work in the same section in order to accompany one another on the walk between work and home. The boss relented and allowed them to work in the weaving section as well. ${ }^{56}$ An older, skilled weaver from the same region as the children trained them with enthusiasm. Later, the three children joined that older worker in the conflict with the people of al-Mahalla (Maballawiyya) who attacked factory workers in a desperate attempt to drive them out of town. Al-Khuli and his friends are thus prime examples of the informality embedded within the process of recruitment and of mediation based on loyalty to geographical origin.

Behind the seemingly arbitrary system of recruitment, there were intricate structures at work. Agrarian pressures on land made labour abundant, and kinship, friendship, and geographical origin became crucial to acquiring an industrial job. In a milieu of corruption and informality, the selection process allowed workers who enjoyed good relations with their supervisors to mediate in the process to help others get jobs. The fact that a rank-and-file worker was able to mediate in the selection process was a significant sign of how so-called powerless workers were willing and able to manipulate the system to their advantage, thereby acquiring a measure of balance in their unjust relations with the giant company. It was further remarkable that rank-and-file workers were able to secure jobs for others while powerful politicians and rich businessmen failed to do so.

The unwritten policy was to ignore the recommendations and endorsements of outsiders. ${ }^{57}$ Top-level personnel were recruited from among Cairo-based, government civil service employees with higher education and technical training. They viewed themselves as part of the modernization

57. Harbison and Ibrahim, Human Resources for Egyptian Enterprise, p. 73. 
and nationalism ethos. ${ }^{8}$ Their experience in public administration brought with it the assets as well as many of the shortcomings of bureaucratic organization. They demonstrated the national aspiration to create modern subjects through authoritative coercion. As highly skilled technicians, these top managers were hardworking and opposed nepotism. Notables of the town, including company board members, often failed to mediate the hiring process to get people jobs. 'Abd al-Hayy Pasha Khalil - politician, wealthy businessman, and MCSW board member - failed, for example, to secure jobs for a retired policeman and a bankrupt handloom weaver. ${ }^{59}$

\section{MAKING AND BREAKING CLASS SOLIDARITY}

The informality of recruitment practices had contradictory implications for shopfloor relationships among workers and between workers and their superiors. On the one hand, it led to the reproduction of relations of dependence and indebtedness right down the chain of social relationships in and around the factory. On the other hand, providing assistance with recruitment in return for wage-sharing became a widespread practice, tying the mutual economic advantages into the mechanisms of social solidarity that enabled workers to exercise such influence over recruitment.

Yet, in many cases, worker intervention in the processes of recruitment and hiring created a potential source of violence among workers. When mediation was conducted out of communal commitment, it served to strengthen communal identity based on geographical origin and kinship, but also consequently weakened class solidarity. When mediation was based on a financial agreement, workers fought violently, sometimes causing fatalities, when someone failed to respect the terms of the arrangements agreed. We can trace violent incidents reported to the court and peaceful incidents mentioned in less than a handful of available biographical sources, noting that many other violent and peaceful incidents must have escaped these records.

One of the most violent confrontations over such a financial agreement occurred between two twenty-five-year-old workers, 'Abd al-Salam al-Sayyid and al-Sayyid 'Uthman al-Samanudi, from the nearby town of Samanud. ${ }^{6}$ Al-Sayyid helped his co-villager, al-Samanudi, secure a job at the company, and, based on what had become convention, al-Sayyid assumed it was his right to receive a portion of al-Samanudi's wages.

58. In dedicating The Mahalla Report, the American researcher William Morris Carson depicted Abd al-Hamid Hamdy, the general manager of the MCSW, as "Egypt's enlightened captain of industry".

59. 'Abdin Archive in Dar al-Watha'iq al-'Umumiyah, Mahfazah, 44I, "Iltimasat talab wazifa, 1939-1944" [Petitions on Job Requests, 1939-1944] and Mahfazah, 402, "Iltimasat i'anat, 1947-1949" [Petitions for Financial Aid, 1947-1949].

60. Tanta Criminal Court Record 1939/7443/1864. 
Al-Samanudi refused to pay, which troubled their co-villager colleagues. On 29 August 1939, al-Samanudi and al-Sayyid confronted each other on their way to work and got into a violent fight. Three of their colleagues witnessed the fight but decided not to intervene and continued on their way to work. In the course of the fight, al-Sayyid broke al-Samanudi's skull, causing al-Samanudi severe, permanent disability. The injury to his skull exposed al-Samanudi to infection, endangering his life. Al-Samanudi also struck al-Sayyid but caused him only minor injury that required less than twenty days' treatment.

In yet another case, seventeen-year-old Lutfi Hamid Muharram travelled from his village to al-Mahalla so that his co-villager, Salama Muhammad Mustafa, could help him get a factory job at the MCSW. ${ }^{61}$ Their financial agreement extended beyond mediation in the hiring process to include shared housing and living costs. Such agreements were common among workers and were always strictly verbal. Financial disagreement between the two broke out, however, soon after Muharram acquired a job. Although Mustafa willingly chose to leave his own room, the two got into a violent confrontation during the moving process. Muharram stabbed Mustafa three times with a knife, causing him serious injury.

Even in cases where both sides honoured their financial agreements and the hiring process passed off peacefully, newly hired workers often felt exploited by their colleagues, whether or not they were co-villagers. Mediators were able to manipulate the system to augment their incomes, but such opportunistic acts came at the cost of the welfare of their fellow workers. These acts placed great financial burdens on their peers, exploiting them and depriving them of a portion of their much-needed incomes. As Muhammad Shata's biography reveals, it was simply too difficult for those forced to pay a percentage of their meagre, hard-earned wages to feel any solidarity or unity with their mediating co-workers. ${ }^{62}$ Some of them resented the exploitation by their co-workers even more than the exploitation by the company.

A representative case is that of weaving-section worker, Ahmad al-Tur. Following the first major workers' strike in 1938, al-Tur was the only worker to testify against his striking colleagues, which led to the conviction of fifty-two people. ${ }^{63}$ After the trial, al-Tur enjoyed favourable treatment by the company's administration, particularly from the company guards and officers. He took advantage of his heightened status to mediate for those who sought jobs in the company in return for a fixed fee. As a reward for spying on his colleagues, his mediation efforts were always accepted.

6r. Tanta Criminal Court Record 1940/7443/1905.

62. Al-Sa'id, Arshif al-Yasar, p. 284.

63. Misdemeanour 1938/6776/1865. 
He was despised by his colleagues and over time became a burden on the administration. He was sent to trial when he was caught stealing company property. Among the many workers who testified against him were those forced to pay him for getting them jobs. ${ }^{64}$

The clustering in particular neighbourhoods of family members and covillagers working at the company was a by-product of the workers' ability to participate in labour mediation. Moreover, living and working conditions served to cement the groupings of workers. The lack of official training, orientation, and industrial safety systems made such groupings vitally important for the safety and protection of unskilled workers with no prior machinery experience. Although the MCSW was quite generous in providing top managerial and administrative employees with overseas training, it invested little time and resources in the training of rank-andfile workers. Workers had to learn by watching others. The philosophy, as described by one administrator, was: "The worker is like a person who has never been swimming and is thrown into the river. He either sinks or swims purely on the basis of his own instincts." ${ }^{65}$ Such practices evoke the contemporary system of Bengal's jute factories. ${ }^{66}$

The general practice was to assign new workers to help older workers. If the new recruit was a good observer and imitator, he might acquire the skills necessary to perform the job. Older workers, on the other hand, were often reluctant to teach new recruits their skills out of fear that they might be replaced by younger workers earning lower wages. ${ }^{67}$ If the new worker was a relative or came from the same village, however, the senior worker might take an interest. Training in such cases was likely to be based upon personal considerations and kinship. This system emphasized communal bonding and deepened divisions among workers, which fragmented their sense of solidarity rather than built a sense of professionalism. Meanwhile, bosses and supervisors were irritated by these kinship groupings, believing that they disrupted the company work system. For example, Lutf allah Rizq went to check on and help his newly recruited brother, and when twenty-year-old section supervisor 'Abd al-'Aziz Hassan al-Mallah caught Rizq doing this, he hit him with a handloom shuttle. $^{68}$

Groupings could develop not only from communal-based hiring mediation and informal skills training but also the sharing of living arrangements. Since newcomers often relied on their relatives and co-villagers to get them

64. Misdemeanour $1942 / 6790 / 960$.

65. Harbison and Ibrahim, Human Resources for Egyptian Enterprise, p. 84.

66. Chakrabarty, Rethinking Working-Class History, p. 92.

67. In one such case, Ahmad Muhammad 'Isa refused to train Nasr Muhammad al-Sayyad; then the latter punched him; Misdemeanour 194I/6789/1362.

68. Misdemeanour $1937 / 6774 / 3728$. 
jobs, they also very often shared housing. This led to the tendency for clusters of workers from the same village to share rooms or live in the same area. Such communal concentrations served several purposes simultaneously. Accompanying each other on their trips between work and home provided them with much-needed protection and a sense of familiarity. Dividing the cost of rent also reduced their living costs and ensured communication with their families because a room-mate visiting their home village could carry money, messages, and other provisions between roommates and those families. ${ }^{69}$

This is not to say that such groups did not experience internal disagreements and fights. A geographical cluster could even be shattered, depending on the severity of a disagreement between two individuals in the group. For example, seven teenage workers from the nearby town of Samanud mediated for each other in securing positions at the company. Thanks to the mediation of one supervisor among them, they all succeeded in acquiring jobs. They all worked in the yarn section of shopfloor number 3 and shared a single room as living accommodation. One night, two of them started to argue over possession of a mat they used to sleep on. When others intervened to contain the fight, the entire group split into two opposing sides, and they all suffered physical injuries. ${ }^{\circ}$

Workers were likewise divided into competing groups. Geographical origin, as I have demonstrated elsewhere, played a divisive role among the factory workers of al-Mahalla in a manner similar to racial divisions among American workers. ${ }^{7 \mathrm{I}}$ Yet, kinship was also a significant factor in the creation of a violent atmosphere at the factory and in workers' slums. $^{72}$ For example, supervisor Aziz Ghubriyal afandi beat teenage worker 'Ashmawi Muhammad 'Ashmawi during his night shift. At the end of the shift 'Ashmawi and his father, who was working the same shift, along with four other company workers (their neighbours from the adjacent workers' slum of 'Izbat Abu Gahsha), waited for Ghubriyal at the company gates. Armed with sticks, they dragged Ghubriyal and threatened to kill him in revenge for beating 'Ashmawi's son. Ghubriyal was lucky that a policeman intervened and saved him. ${ }^{73}$ In a similar case,

69. Although this pattern of communication between workers in al-Mahalla and their families in their home villages took place efficiently on a regular basis, court records show that it was not always risk-free. In some cases workers did not pass on money to their families or provisions to their co-workers; in other cases a group of villagers fought over splitting the cost of transporting provisions.

70. Misdemeanour 1938/6775/620.

7I. Heerma van Voss and Van der Linden, Class and Other Identities, pp. I-4I, and Hanan Hammad, "Mechanizing People, Localizing Modernity: Industrialization and Social Transformation in Modern Egypt" (Ph.D. thesis, University of Texas, 2009).

72. Hammad, "Mechanizing People, Localizing Modernity", especially ch. 5, pp. 173-245.

73. Misdemeanour $1939 / 6779 / 727$. 
Ahmad al-Su'udi rushed to help his brother when he heard him screaming on the shopfloor. Al-Su'udi forced the supervisor, Suliman Mar'i, to stop hitting his brother with a stick. After work, the two brothers and the supervisor met outside the company gates for another round of violence, in which al-Su'udi was injured. ${ }^{74}$

It is reasonable to assume that such dramatic confrontations widened the rift between rank-and-file company workers and the supervisors and guards (ghafar). Two brothers, Abbas and Ali Fahmi 'Isawi as-Su'udi, exchanged blows with company guard Muhammad Musa Khalifa on 23 March 1938. A few anonymous other workers participated on the side of Khalifa, who reported that the fight erupted between him and one of the brothers because the latter was allowing a third person to enter his house while he was away. ${ }^{75}$

What was even more dangerous was the daily agitation among rankand-file workers that extended beyond the shopfloor and into their homes and on to the roads between the two destinations. A disagreement broke out on the shopfloor between sixteen-year-old Husayn 'Ali al-Zini and his colleague, Qasim Ahmad 'Abd an-Nabi, on 7 March I939. On their way back to their homes in the workers' slum of 'Izbat Raghib, al-Zini and the twenty-two-year-old fellow company worker Yusuf, along with eight other people, waited in ambush in a dark alley to attack 'Abd an-Nabi with a hammer. 'Abd an-Nabi received blows to his head; he lost the vision in his right eye. Al-Zini was sentenced to two years in jail, with hard labour, and had to pay EGP 50 in compensation to the victim. ${ }^{76}$

A similar, explosive confrontation took place in the weaving section, with two brothers clashing with two other workers. The incident began with a disagreement between Muhammad Mahmud al-Minufi and Musa 'Abd al-Maqsud Abu an-Naga in the weaving section, and a fight erupted when al-Minufi's twenty-year-old brother, Tawfiq, and others joined in. Abu an-Naga hit Tawfiq on the head with a large piece of heavy wood. Tawfiq was taken to hospital in a critical condition, and underwent surgery. Doctors had to remove pieces of Tawfiq's skull from his brain, which impaired his ability to work and placed his life in danger from exposure to brain infection. Tawfiq's injury resulted in a permanent disability, and Abu an-Naga was sentenced to five years in prison. ${ }^{77}$

Despite the importance of worker solidarity based on geographical origin, bonds based on kinship usually prevailed. The brothers 'Abdu and Ibrahim Mahmud Ghayra (twenty-eight and twenty-three years old respectively) met their rivals Muhammad 'Ali Darwish and Muhammad

74. Misdemeanour $1938 / 6777 / 1742$.

75. Misdemeanour I $938 / 6776 / 975$.

76. Tanta Criminal Court Record 1939/744I/879.

77. Ibid. 
Muhammad al-Qutt after work on the al-Mahalla-Samanud road (all of them hailed from the village of Samanud). After an argument, the brothers stabbed their rivals, who were riding a bicycle, causing them serious injuries. ${ }^{78}$ The privilege of kinship was also evident within the same geographical cluster. The brothers Fathi and 'Abd al-'Aziz Hassan al-Muslimani, company workers aged sixteen and twenty respectively, struck their co-worker and room-mate Muhammad al-Sayid Fadil because he failed to bring home the food they had ordered him to bring. ${ }^{79}$ Geographical origin and kinship thus worked together in simultaneously cementing and dividing workers' groupings. In March 1936 a group of company workers became involved in a confrontation against several townspeople from al-Mahalla (Maballawiyya) in the workers' slum of 'Izbat al-Sa'ayda; three brothers sided with the workers and two sisters sided with the Maballawiyya. ${ }^{80}$

\section{CONCLUSION}

Workers who mediated in the MCSW hiring process to obtain and maintain jobs for themselves and others manifested their ability to empower themselves in the face of the giant, nationalist company. They mediated to select and train their kin and co-villagers, manipulated the hiring process to embezzle money by adding fake names to the payroll, and secured jobs for those who did not meet the company's medical and legal qualifications. In doing so, workers augmented their income through commission, graft, or fraud, and they brought their social networks from their native villages to their new home town. The familial and village groupings that developed as a by-product of worker mediation resulted in explosive moments of violence among workers. Occasionally, financial disagreement between workers and their mediators led to violent confrontation. Polarization based on kinship prevailed among groups of alien workers.

It must also be noted, however, that working and living in an environment dominated by exhaustion, alienation, and disorientation among young workers was commonly the main, underlying trigger for daily arguments and disagreements even within the same group of kin or co-villagers. Diverse geographical origins and social cultures combined with the experience of having to live in overcrowded and dilapidated urban slums caused workers' groups to lack cohesion based on social codes or authoritative reference to solve disagreements in a calm or nonviolent manner.

80. Misdemeanour 1936/6767/1019-1025. For similar cases see Misdemeanour 1942/6791/1628 and Misdemeanour 1937/6770/572. 
Although familial and communal groupings served to divide workers, these groupings also facilitated their transformation and adaptation to urban industrial life and shaped their social consciousness as a distinctive urban group. Sharing skills on how to operate machinery safely and providing protection at work and at home reduced the feeling of alienation for many workers, and gave them a much-needed sense of familiarity in their lives in al-Mahalla. More importantly, the groupings provided them with work and helped to sustain them in their jobs. As in the case of interwar India, kinship and village connections added an economic function to "primordial" solidarity and provided workers with accommodation and shelter during times of sickness and hardship. ${ }^{81}$

During the major workers' strikes of 1938 and 1947 , workers living in slums survived on a system of credit. Co-villagers and relatives sheltered newcomers until they were able to secure jobs in the company. Worker mediation in the company hiring process to secure employment for others empowered labourers in the face of the capitalist factory, but also created divisions among the workers themselves. Worker empowerment and division formed their consciousness as a distinct community - much like a separate class - in relation to the local capitalist system and their new urban surroundings. 